\title{
Az osztrák csendőrség 1848-1938
}

DOI : 10.31627/RTF.XXIV.2014.39-40-41-42N.15-22P

Az osztrák csendőrség - Európa valamennyi csendőrségéhez hasonlóan — a francia csendőrségből eredeztethető. Franciaországban több évszázados fejlődés során alakult ki a csendőrség, mely a XVIII. század végéig Maréchaussée névre hallgatott. A testület kezdetben katonai rendőrség volt, majd fokozatosan - a polgári lakosság igénye nyomán — terjedt ki a hatásköre háború idején a hadmüveletei területek polgári lakosságára is, majd békeidőszakban is a polgári lakosságra az ország egész területére kiterjedően, de csak vidéken. ${ }^{1}$

A NAPÓLEON-i császárság időszakában terjedt el — a francia közigazgatás részeként — a csendőrség intézménye, a Francia Császárság vonzáskörébe tartozó országokban. Így került a csendőrség Lombardiába, amely Napóleon császárságának idején a HABSBURG-birodalom fennhatósága alól a Francia Császárság felügyelete alá került. ${ }^{2}$

Mivel a lombardiai csendőrség jó hatásfokkal müködő szervezet volt, — miután Lombardia visszatért a HABSBURG-birodalomba - ezért a HABSBURG-adminisztráció megtartotta. Ez a csendőr ezred vált a HABSBURG-birodalomban az 1848-1849-es magyar forradalom és szabadságharc leverése nyomán kiépülő birodalmi csendőrség mintájává. Az 1849. III. 4-én oktrojált összbirodalmi alkotmány kimondta, hogy ,a birodalom belső biztonságának az ôrzése birodalmi ügy.” ${ }^{3}$ Ez képezte az alapját annak, hogy Ferenc József neoabszolutista birodalmában létrehozták a HABSBURG Birodalmi Rendőrséget és a HABSBURG Birodalmi Csendőrséget a vidékre, illetve a városokra kiterjedően. A HABSBURG-birodalom csendőrségének a létrehozását Ferenc József 1849. VI. 8-án rendelte el. ${ }^{4}$

A birodalmi csendőrség vezetőjének Julius Jacob von HAYNAU táborszernagy jobb kezének számító báró Johann Franz KEMPEN von Fichtenstamm altábornagyot a budai katonai kerület parancsnokát nevezte ki az uralkodó - a csendőr föparancsnoki tisztsége meghagyásával - a birodalmi rendőrhatóság vezetőjévé. E szervezet - melyet az uralkodó Legfelsőbb Rendőrhatóság elnevezéssel 1852. IV. 25-én, az 166/1852. számú leirattal állított fel ${ }^{5}$, mely valóságos „Birodalmi Biztonsági Főhivatal"-ként müködött, hiszen a csendőrség mellett a HABSBURG-birodalom másik legfontosabb rendvédelmi testületének a birodalmi rendőrségnek is a legfelső irányító és felügyeleti szervezete volt. $^{6}$ A Legfelsőbb Rendőrhatóságot létrehozó uralkodói leiratban az olvasható, hogy „ . . . a Legfelsőbb Rendőrhatóságnak müködését föként azon veszélyek megelőzésére és felszámolására kell irányítania, amelyek az állami intézményeket és egyáltalában a fennálló államrendet fenyegetik". A Legfelsőbb Rendőrhatóságot az uralkodó saját, közvetlen alárendeltségébe helyezte. ${ }^{7}$

A Legfelsőbb Rendőrhatóság 1859. VII. 21-ig müködött, amikor a vesztes itáliai háborúval együttjáró belpolitikai irányváltás részeként doktor Alexander BACH belügyminisztert és báró Johann Franz KEMPEN von Fichtenstamm táborszernagyot is felmentették. Egyben pedig a Legfelsőbb Rendőrhatóságot rendőrminisztérium váltotta fel. Az uralkodó az 1859. XI. 14-én kelt legfelsőbb elhatározásával elrendelte, hogy „ . . . a csendőrség katonailag szervezett biztonsági testületként továbbra is fennmaradjon . . k katonai és fegyelmi vonatkozásban a hadsereg-föparancsnokság, míg szolgálati és gazdasági vonatkozásban a belügyminiszter alárendeltségében áll . . ." Az uralkodói döntés szerint a csendőrség hatásköre a közbiztonság és a közrend, és a köznyugalom céljára korlátozódott. A helyi rendőri ügyekben pedig csak felügyelö és a községi szervezeteket támogató befolyást kellett gyakorolnia. A csendőrségnek a rend, a nyugalom és a biztonság fenntartására hivatott politikai hatóságok rendelkezésére is kellett állnia, ezen túlmenően pedig a császári-királyi polgári és katonai hatóságok megkereséseinek is eleget kellett tennie. E szabályozás tartalma lényegében végigkísérte az osztrák csendőrséget fennnállása teljes időszakában annak ellenére, hogy a testület müködését több ízben szabályozták. 1849 és 1867 között a HABSBURG-birodalom csendőrségét több ízben átszervezték. A testület létszámát és a szervezeti egységek számát több ízben növelték, illetve csökkentették. A testület létszáma 7923 és 18985 fő között, míg a csendőr ezredek száma 19 és 9 ezred között mozgott. ${ }^{8}$

A kiegyezéssel a Magyar Királyságban a csendőrség megszünt. A HABSBURG-adminisztráció részéről ugyan felvetődött annak a gondolata, hogy a Magyar Királyság terültén müködő csendőr csapatok maradjanak fenn a magyar kormány felügyelete alatt, a magyar politikai vezetés azonban erre nem volt hajlandó. A HABSBURG Birodalmi Csendőrség ugyanis - a közbiztonság óvása mellett - a magyar hazafiak üldözéséböl is derekasan kivette a részét. A magyar kormány pedig nem kívánt ilyen szervezettel, illetve ilyen testület személyi állományával együtt tevékenykedni. A Magyar Királyságban 1867 . V. 8-án feloszlatták a császári csendőrséget. ${ }^{9}$

Az Osztrák-Magyar Monarchia dualista államalakulatának másik felében az Osztrák Császárság- 
ban azonban a korábbi birodalmi csendőrségnek az Osztrák Császárság területén müködő része fennmaradt és tovább müködött. A dualizmus időszakában azonban az Osztrák Császárság csendőrségét több ízben is modernizálták oly módon, hogy azok kihatottak a két világháború közötti időszakra is. 1870. II. 15-ei kormányátalakítás kapcsán az Osztrák Császárság csendőrségének az irányítása — a rendvédelem feletti teljes kompetencia részeként - a Honvédelmi és Közbiztonsági Minisztériumtól átkerült a Belügyminisztériumhoz. Ezzel egyidőben pedig a korábbi gazdatárca elnevezése Honvédelmi Minisztériumra változott. Ezzel az Osztrák Császárság csendőrsége ismét az 1859. évi uralkodói leiratban foglalt kettős alárendeltséget megvalósító helyzet előtti kettős alárendeltségbe került vissza, hiszen - mivel a csendőrök személyükben katonának minősültek - a testület személyi ügyei tekintetében az Osztrák Honvédelmi Minisztérium hatásköre megmaradt. ${ }^{10}$

1873-ban az Osztrák Császárság valamennyi örökös tartományában felállítottak egy-egy csendőr parancsnokságot. Ezek a Magyar Királyi Csendőrség kerület-parancsnokságainak feleltek meg. 1880ig az Osztrák Császárság kiegyezés évi csendőrségének a létszámát mintegy 1/3-ával növelték, így a testületi létszám 8268 före nőtt. ${ }^{11}$

Az Osztrák Császárság csendőrségének a kötelékébe azonban nem tartozott bele Bosznia-Hercegovina Csendőrsége. Bosznia-Hercegovina ugyanis nem tartozott sem az Osztrák Császársághoz, sem pedig a Magyar Királysághoz. Bosznia-Hercegovinát a két társország közösen irányította a közös pénzügyminiszter által. Bosznia-Hercegovinában is müködött ugyan csendörség, ez a szervezet azonban független volt az Osztrák-Magyar Monarchia mindkét társországának csendőrségétöl. A Bosznia-Hercegovina-i Csendörség — a méreteit tekintve — megfelelt egy örökös tartományi csendőrségnek, illetve egy magyarországi csendőr kerületnek. ${ }^{12}$

A XIX-XX. század fordulóján az Osztrák Császárság területén 14 tartományi csendőr-parancsnokság (magyarországi megfelelői a csendőr kerület-parancsnokságok), 162 csendőr szárny-parancsnokságot irányított (magyarországi megfelelöi a csendőr szárny-parancsnokságok), amelyeknek az alárendeltségeibe 398 körzeti csendőr csapat-parancsnokság tartozott (magyarországi megfelelöjük a csendőr szakasz-parancsnokság). A testület legkisebb szervezeti egységei pedig az örsök voltak, összesen 4439 örs múködött. A testület személyi állományának a létszáma pedig 18315 fö volt. Az utolsó békeévben az Osztrák-Magyar Monarchia társországaiban a Magyar Királyságban 8 csendőr kerületparancsnokság, 57 csendőr szárny-parancsnokság, 136 csendőr szakasz-parancsnokság és 683 csendőr járásőrmesterség, továbbá 2028 csendőr őrs müködött. A Magyar Királyi Csendőrség személyi állományának a létszáma pedig mintegy 12000 föt tett ki. ${ }^{13}$

Az Osztrák Császárság örökös tartományainak a teljes területe 323577 km² volt, ahol 24411858 fö élt. ${ }^{14}$

Az első világháború veresége nyomán az Osztrák Császárság megszünt. Az osztrák-németek 1918. X. 21-én létrehozták a német-ausztriai — a nem német lakosságú örökös tartományok nélküli Ausztria — ideiglenes nemzetgyülést, amely 1918. X. 30-án megválasztotta a végrehajtó hatalmat ideiglenesen gyakorló államtanácsot. 1918. XI. 10-én kikiáltották a köztársaságot, elnököt választottak és kormányt alakítottak. Már 1918. X. 30-án olyan döntést hoztak, hogy valamennyi irányító és végrehajtó testület — beleértve a rendvédelmi testületeket is - a korábban hozott törvények, rendelkezések és elöírások szerint folytassa tevékenységét. A csendőrség esetében azonban szükségesnek tartották a szabályozás módosítását. Eszerint az addig katonailag szervezett őrtestületet átminősítették polgári fegyveres örtestületté. Ebből fakadóan pedig a csendőrök katonából hivatalnokká váltak, azaz a státuszuk azonossá vált a rendőrökével, akik korábban is hivatalnoknak minősültek. ${ }^{15}$

Az 1919. IX. 10-ei Saint-Germain-i államszerződési diktátum megtiltotta Ausztria Németországhoz csatlakozását, amit pedig Ausztria szabad államként már törvényesen kinyilvánított. Ez a helyzet szükségessé tette az átvezető alkotmányos rendezést. A rendvédelem terén ez azt jelentette, hogy a csendőrséget és a rendőrséget átkeresztelték Osztrák Szövetségi Csendőrséggé és Osztrák Szövetségi Rendőrséggé, majd 1923-ban mindkét rendvédelmi testület legfelsőbb irányítása átkerült a belügyminisztériumtól a kancellária hivatalához.

Az Osztrák Szövetségi Rendőrség fő irányítója a bécsi rendőrigazgató volt, az Osztrák Szövetségi Csendörség vezetését pedig a központi felügyelő látta el amely beosztást 1933-ban főfelügyelői elnevezésü tisztségre változtattak. Ugyanezen évben a tartományokban a rendőrség irányítását a tartományfönök alárendeltségébe tartozó tartományi biztonsági igazgató vette át. A tartományi biztonsági igazgatókat pedig a kancellária hivatalban újonnan felállított Közbiztonsági Főigazgatóság vette át.

Az ANTANT hatalmak nyomására polgárosított osztrák csendőrség azonban nem tudta megállni a helyét akkor, amikor komolyabb összetüzésre került sor Ausztriában. 1929. VIII. 18-án St. Lorenzben 
a Schutzbund összetüzésbe került a Heimwehrrel, melynek következtében 4 halott és 60 sebesült maradt az összecsapás valóságos csatatér helyszínén. A vérontást valószínúleg meg lehetett volna akadályozni, ha megfelelő létszámú csendőri erőt tudtak volna összevonni az összecsapás .helyszínén. A 4 fös helyi csendőr örsöt azonban 25 fönyi csendőrrel tudták megerősíteni, mivel a testület összpontosítási lehetőségei rendkívül kedvezőtlenek voltak. ${ }^{16}$

Az osztrák csendőrség létszáma 5680 fö volt, a csendőrök 1300 őrsön teljesítettek szolgálatot. Az őrsök létszáma oly csekély bolt, hogy még a rendes nyomozó szolgálatot sem tudták ellátni. Ezekröl a kislétszámú csendőr őrsökről még egy-egy főt sem lehetett elvonni. Karhatalmi alakulatokkal pedig az osztrák csendőrség csak a tartományi csendőr-parancsnokságok székhelyein — nem állandó jelleggel — müködő próbacsendőriskolák és az ugyancsak időnként müködő Gratz-i őrsparancsnokképző tanfolyam formájában rendelkezett.

A csekély létszám miatti előnytelen helyzetet pedig fokozta, hogy az osztrák csendőrség hírösszekötetése kiépítetlen volt. A csendőr örsöknek csupán kis része rendelkezett saját telefonnal. A telefonjaikat a helyi postahivatalban intézték. A postahivatalok azonban csupán a hivatali időben voltak nyitva. Sok örsnek az állomáshelyén egyáltalán nem volt telefon, velük küldöncökkel tartották a kapcsolatot.

E hátrányos helyzet felszámolása érdekében az osztrák csendőrségnél:

- a kis őrsöket nagyobb létszámú őrsökbe vonták össze;

- a központi fekvésü településeken, közlekedési centrumokban tartalék alakulatok szervezésébe kezdtek;

- az őrsöket ellátták telefonállomásokkal;

- a testületet fokozatosan csapatszállító gépjármüvekkel látták el, kezdetben 100 motorkerékpárt kapott a csendőrség;

- elkezdték a csendőrség fegyverzetének a korszerüsítését és sorozatlövő fegyverekkel való felszerelését. $^{17}$

A kivételes helyzetektől eltekintve azonban az Osztrák Szövetségi Csendőrség jól müködött. 1930-ban a testület tagjai 305232 személyt jelentettek fel és 28222 föt vettek őrizetbe. 10273 esetben végeztek házkutatást a csendőrök. Emellett a testület 6277 esetben nyújtott őrkíséretet és 2078 esetben teljesített karhatalmi szolgálatot. A közigazgatási hatóságok felhívására pedig 5530 esetben valósított meg tolonckíséreti szolgálatot. Végezetül pedig a testület tagjai 12711 esetben láttak el szolgálatot elemi csapások, balesetek, eltüntek utáni kutatások kapcsán. ${ }^{18}$

Az Osztrák Szövetségi Csendőrség az 1934 februári forradalom időszakára már az 1929. évi állapotánál jóval kedvezőbb helyzetben volt. Annak ellenére tehát, hogy az osztrák szocialisták póthadserege a Schutzbund 1934. II. 12-én számos kisebb csendőri alakulatot meglepetésszerüen lerohant, a csendőrség az osztrák haderővel, rendőrséggel és a polgári védőalakulatokkal (Schutzkorps) az osztrák szocialista fegyveres felkelést leverte. ${ }^{19}$

A felkelés hírére a kormány a rendőrséget, csendőrséget, hadsereget riadóztatta, kihirdette az ostromállapotot és feloszlatta a szociáldemokrata pártot. A Schutzbund azonban az elrejtett jelentős fegyverkészleteit felhasználva fegyveres felkelésbe kezdetett, melynek során nem csupán sorozatlövő fegyvereket, hanem gyalogsági ágyúkat is bevetettek mindkét részröl. A felkelést azonban néhány nap alatt leverték. ${ }^{20}$

Az osztrák csendőrség és az osztrák rendőrség is azt a taktikát követte, hogy a kislétszámú őrszobákat és őrsöket feladta, az ott szolgálatot teljesítő csendőröket és rendőröket pedig összevonta, mivel a fegyveres felkelőknek csak viszonylag nagyobb létszámú alakulatok állhattak ellen. Az osztrák csendőrség sorozatlövő fegyverekkel való felszerelése minden bizonnyal számos csendőr életét mentette meg. Az 1934. II. 12-től 1934. II. 15-éig tartó harcokban 12 csendőr vesztette életét, valamint 22 testületi tag megsebesült. Kiválóan vizsgázott a testület motorizációja. A tartományi csendőr-parancsnokságok alárendeltségében létrehozott csendőr kiegészítő osztagok (csapaterős karhatalmi alakulatok) kiváló hatásfokkal müködtek. Mindig oda irányították ezen alakulatokat, ahol a helyi csendőri erőknek erősítésre volt szükségük. A motorizált csendőr osztagok rövid időn belül elérték a bevetésük helyszínét. Ezen erösítés birtokában pedig a szorongatott csendőröknek sikerült .leverniük. ${ }^{21}$

A csendőr kiegészítő osztagok mindegyike 3 gépkocsival rendelkezett. Ezek voltak:

- 1 csukott csapatszállító gépkocsi (32 fö);

- 1 nyitott ponyvafedelü gépkocsi (36 fó);

- 1 úgynevezett gyors teherkocsi (amely teher, vagy 10 fő szállítására volt berendezve). 
Az Osztrák Szövetségi Csendőrség számára további hasznos segítséget jelentettek az úgynevezett .riadó szakaszok. A riadó szakaszok személyi állományát (16-30 fö) az őrsök személyi állományából vonták össze a járások (Bezirk) székhelyeire. A riadó szakaszokat géppuskával is felszerelték. A motorizált szállító eszközeiket pedig a lakossági gépjármúvek közül rekvirálták. A technika mellett a csendőrök tevékenységét eredményesen segítette a védőrség (Schutzkorps). A védörség — amely önkéntes jelentkezésen alapuló felfegyverzett szervezet volt és leginkább a nemzetőrséghez, vagy a polgárőrséghez hasonlítható - tagjaira nem csupán a harcokban lehetett számítani, hanem nélkülözhetetlen támogatást nyújtottak a csendőrség számára azzal, hogy a testületet mentesítették a fogolyőrzés és fogolykíséret, a mütárgyak őrzése stb. teendői alól. Ezzel pedig elősegítették a koncentrálható csendőri erők létszámának a gyarapodását. ${ }^{22}$

Az Osztrák Szövetségi Csendőrség átfegyverzése, motorizációja, szervezetének módosítása azonban nem lett volna önmagában elégséges ahhoz, hogy fegyveres felkelés esetén eredményesen müködjön. A legfontosabb tényezőnek a személyi állomány bizonyult. A csendőrség vezetői a katonai vezetés elveivel tisztában voltak és azt a gyakorlatban is helyesen alkalmazták. A legénység pedig a harcászati szabályzatban foglaltaknak megfelelően és bátran cselekedett. A csendőrségen belüli alá- fölérendeltségi rendszer és a testület katonai szellemisége voltak azok a humán körülmények, amelyek lehetővé tették a materiális feltételek eredményes alkalmazását. A testület azon humán viszonyai segítették elő a leghatékonyabb módon a Schutzbund elleni eredményes fellépést, amely szálka volt a szociáldemokraták szemében.

Az Osztrák-Magyar Monarchia összeomlásakor az osztrák baloldalnak az ANTANT támogatásával sikerült is elérnie, hogy a csendőrséget katonailag szervezett őrtestületből polgári őrtestületté alakítsák. Ebből fakadóan a személyi állomány elvesztette katonai jogállását és rendfokozatát, helyette tisztviselőkké váltak. Nem lehetett azonban eltörölni a testület személyi állományának katonai szakismereteit és szellemiségét, amely az állam- és a társadalmi rend védelme érdekében hathatósnak bizonyult 1934 februárjában. ${ }^{23}$

A történelem fintora, hogy a közép-európai birodalom ideája — a nagynémet egység gondolata hozta létre és szüntette meg az ausztriai csendörséget. Az 1848-1849-es magyar forradalmat és szabadságharcot cári segédlettel leverő HABSBURG-hatalom számára alapvető kérdés volt, hogy a HABSBURG-birodalmat milyen külpolitikai irányultsággal szervezzék újjá. Ferenc József követei 1848. IV. 5-én kivonultak a frankfurti német birodalmi gyülésből, ezzel juttatva kifejezésre elutasításukat a frankfurti gyülés koncepciójával, mely szerint a német egységhez csak a német szövetséghez tartozó tartományaival — azaz a német nyelvü lakossággal rendelkező tartományokkal — csatlakozhatott volna a HABSBURG-birodalom. A koncepciót a frankfurti össznémet parlament 1848 őszén határozat eröre is emelte. ${ }^{24}$

Ezzel viszont lehetetlenné tette, hogy a HABSBURG-hatalom vezető szerephez juthasson a Német Szövetségben. A HABSBURGok által vezetett német szövetség ambíciójának gondolata alkotta Félix SCHWARZENBERG herceg (miniszterelnök 1848. XI. 21. - 1852. IV. 5.) külpolitikájának vezérlő elvét. Sógora Alfred Candidus Ferdinand zu WINDISCHGRÄTZ herceg juttatta kormányrúdhoz Európa egyik leggazdagabb emberét. A hatalmas kiterjedésủ csehországi birtokokkal rendelkező család tagjai a HABSBURG-birodalom vezető tisztségeit töltötték be. Félix Ludwig Johann, Fürst zu SCHWARZENBERG herceg Rio de Janerio-tól Szentpétervárig töltött be -diplomata tisztségeket. A nagy birodalmaknál teljesített diplomata szolgálatai elősegítették a részletkérdéseken való felülemelkedés és a nagy összefüggések és tendenciák felismerése képességének a kialakulását. Félix Ludwig Johann, Fürst zu SCHWARZENBERG herceg felismerte, hogy csakis a teljes HABSBURG-birodalom képes megfelelő erőt biztosítani a HABSBURG vezetéssel megvalósuló német egység megvalósításához. Koncepciója lényegét a HABSBURG-Birodalom centralizációja és német tartalmú homogenizációja képezte. A centralizációt sikerült átmenetileg megvalósítania, a homogenizációt azonban nem. Alábecsülte a nemzetek öntudatát. ${ }^{25}$

Ennek a koncepciónak volt a része a birodalmi rendvédelmi modell kialakítása, melynek fontos elemét alkotta a császári csendőrség létrehozása. Az osztrák csendőrség tehát a nagynémet egység gondolatkör termékeként jött létre. És a nagynémet egység megvalósításakor - csaknem egy évszázaddal később - került felszámolásra az Anschlussal. Ez a nagynémet egység azonban már nem a HABSBURG-ház irányításával valósult meg és - a hajdani frankfurti elgondoláshoz hasonlóan csupán a német ajkú Ausztriát foglalta magában. 
Jegyzetek:

${ }^{1}$ GERGELY: 143.p. ; ÖRY

${ }^{2}$ PRESZLY

${ }^{3}$ ZAHAR: Fejezetek az osztrák csendőrség történetéből 1849-1918. 105.p.

${ }^{4}$ Loc.cit. 105.p.

${ }^{5}$ ZAHAR: Tradíció és folyamatosság az osztrák rendvédelmi szerveknél. 67.p. ; Idem: Az Osztrák-Magyar Monarchia örökös tartományainak rendvédelmi testületei. 24-27.p.

${ }^{6}$ Idem: Az osztrák rendvédelmi modell gyökerei. 203-204.p.

${ }^{7}$ Idem: Tradíció és folyamatosság az osztrák rendvédelmi szerveknél. op.cit. 67.p.

${ }^{8}$ Idem: Fejezetek az osztrák csendőrség történetéből 1849-1918. op.cit. 107.p.

${ }^{9}$ DEÁK: 352-353.p.

${ }^{10}$ ZACHAR: Fejezetek az osztrák csendőrség történetéből 1849-1918. op.cit. 108.p.

${ }^{11}$ Az Osztrák Császárságban 14 tartományi csendör parancsnokság müködött, mivel a kisebb szomszédos tartományokra egy-egy tartományi csendőr parancsnok hatósági területe terjedt ki.

Loc.cit.

${ }^{12}$ Loc.cit.

${ }^{13}$ Loc.cit. ; PARÁDI: A Magyar Királyi Csendörség. Az elsö magyar polgári központosított, közbiztonsági örtestület 1881-1945. 54.p

${ }^{14}$ SIXTUES

${ }^{15}$ ZACHAR: Fejezetek az osztrák csendőrség történetéből 1849-1918. op.cit. 109.p. ; Idem: Az osztrák rendvédelmi modell gyökerei. 204-205.p.

${ }^{16}$ Szerkesztőségi közlemény: Átszervezték az osztrák csendőrséget. 801.p.

${ }^{17}$ Loc.cit. 802.p.

${ }^{18}$ Szerkesztőségi közlemény: Az osztrák csendőrség 1930. évi müködése. 503.p.

${ }^{19}$ OLCHVÁRY - RIDEGH: I. rész.

${ }^{20}$ Loc.cit. II. rész.

${ }^{21}$ Loc.cit. IV. rész.

${ }^{22}$ Loc.cit. IV. rész.

${ }^{23}$ Loc.cit. IV. rész.

${ }^{24}$ GALÁNTAI: 18.p.

${ }^{25}$ G.K. COZERING: I.köt. 74-80.p.

Jegyzetekben alkalmazott röviditések:

\section{MONOGRÁFIÁK, KISMONOGRÁFIÁK ÉS HASONLÓ JELLEGŰ KÖTETEK}

G.K. COZERING

GALÁNTAI

PARÁDI: A Magyar Királyi Csendörség. Az első magyar polgári központosított, közbiztonsági örtestület 18811945 .

PRESZLY

SiXTUES

\section{TANULMÁNYOK}

DEÁK

ÖRY
G.K. COZERING: Ehtnographie des Österreichischen Monarchie. [Az osztrák monarchia néprajza.] Wien, 1857, s.n. I.köt.

- GalÁntai József: A Habsburg-monarchia alkonya. Osztrák-magyar dualizmus 1867-1918. Budapest, 1986, Kossuth. 386 p. HU-ISBN 9630925893.

PARÁDI: A Magyar Királyi Csendőrség. Az első magyar polgári központositott, közbiztonsági örtestület 1881-1945. Budapest, 2012, Szemere Bertalan Magyar Rendvédelem-történeti Tudományos Társaság. 281 p. HUISBN 978963084790 0. /A magyar rendvédelem-történet öröksége, 2./ HUISSN 2062-8447.

- PReszly Lóránd: A magyar Királyi Csendörség története 1881-1919. Budapest, 1920, Honvédelmi Sajtóvállalat. 142 p.

- Alexander Sixtues von Reden: Az Osztrák-Magyar Monarchia. [Österreichisch-Ungarisches Monarchie.] Ford. BLAschtik Éva, HuszÁR Ágnes, NÉmeth Mária, VÁRNAI Péter. Budapest - Salzburg, 1989, Széchenyi Kiadó Druckhaus Nomital Bückerdienst. 305 p. HU-ISBN 9630272055.

— DEÁK Ágens: Egy régi politikai rendszerváltás és az államrendőrség 1867. Történelmi Szemle, XLIX.évf. (2007) HU-ISSN 0040-9634.

- ÖRY Károly: A Maréchaussée-tól a Gendarmerie Nationale-ig (a francia csendőrség történeti előzményei). Rendvédelem-történeti Füzetek (Acta Historiae Preasidii Ordinis), VII.évf. (1997) 8.sz. 75-77.p. HU-ISSN 12166774. A tanulmány korábbi változata 1996. október 29-én Budapesten hangzott el a Szemere Bertalan Magyar Rendvédelem-történeti Tudományos Társaság által szervezett rendvédelem-történeti tudományos konferencia-sorozatnak „A napóleoni közbiztonsági örtestület útja Párizstól — Itálián és Ausztrián keresztül - Budapestig" címü VIII. konferenciáján. A publikált tanulmány az előadás javított, bővített és átdolgozott változata. 
ZAHAR: Az Osztrák-Magyar — ZAHAR József: Az Osztrák-Magyar Monarchia örökös tartományainak Monarchia örökös tartományainak rendvédelmi testületei. Rendvédelem-történeti Füzetek (Acta Historiae Prearendvédelmi testületei.

ZAHAR: Tradíció és folyamatosság az osztrák rendvédelmi szerveknél. sidii Ordinis), I.évf. (1991) 1.sz. 17-29.p. HU-ISSN 1216-6774. A tanulmány korábbi változata 1990. április 24-én Budapesten hangzott el a Szemere Bertalan Magyar Rendvédelem-történeti Tudományos Társaság által szervezett rendvédelem-történeti tudományos konferenciasorozatnak „A magyar rendvédelmi testületek és az önkormányzati szervezetek kapcsolata 18481945 ” című I. konferenciáján. A publikált tanulmány az előadás javított, bővített és átdolgozott változata.

ZAHAR József: Tradíció és folyamatosság az osztrák rendvédelmi szerveknél. Rendvédelem-történeti Füzetek (Acta Historiae Preasidii Ordinis), II.évf. (1992) 3.sz. 65-74.p. HU-ISSN 1216-6774. A tanulmány korábbi változata 1991. november 19-én Budapesten hangzott el a Szemere Bertalan Magyar Rendvédelem-történeti Tudományos Társaság által szervezett rendvédelem-történeti tudományos konferenciasorozatnak „,Tradició és korszerüség” címü III. konferenciáján. A publikált tanulmány az előadás javított, bővített és átdolgozott változata.

ZAHAR: Fejezetek az osztrák — ZAHAR József: Fejezetek az osztrák csendőrség történetéből 1849-1918. csendőrség történetéből 1849-1918. Rendvédelem-történeti Füzetek (Acta Historiae Preasidii Ordinis), VII.évf. (1997) 8.sz. 105-109.p. HU-ISSN 1216-6774. A tanulmány korábbi változata 1996. október 29-én Budapesten hangzott el a Szemere Bertalan Magyar Rendvédelem-történeti Tudományos Társaság által szervezett rendvédelemtörténeti tudományos konferenciasorozatnak „A napóleoni közbiztonsági örtestület útja Párizstól - Itálián és Ausztrián keresztül - Budapestig" címü VIII. konferenciáján. A publikált tanulmány az előadás javított, bővített és átdolgozott változata.

ZAHAR: Az osztrák rendvédelmi _ _ ZAHAR József: Az osztrák rendvédelmi modell gyökerei. 203-204.p. Rendmodell gyökerei. védelem-történeti Füzetek (Acta Historiae Preasidii Ordinis), IX.évf. (1999) 10.sz. 202-206.p. HU-ISSN 1216-6774. A tanulmány korábbi változata 1998. szeptember 22-én Budapesten hangzott el a Szemere Bertalan Magyar Rendvédelem-történeti Tudományos Társaság által szervezett rendvédelemtörténeti tudományos konferenciasorozatnak , A nyugati rendvédelem hatása a XIX-XX. századi magyar rendvédelemre" címü X. konferenciáján. A publikált tanulmány az előadás javított, bővített és átdolgozott változata.

\section{CIKKEK}

GERGELY

OLCHVÁRY - RIDEGH: I. rész.

GERGELY Endre: A csendőrség fegyverhasználati joga. Csendőrségi Lapok, XV.évf. (1925) 9.sz. 143-145.p.

OlchVÁRY-Milvius Attila - Ridegh Rajmond: Az osztrák csendőrség az 1934 februári forradalom alatt.

Csendörségi Lapok, XXIV.évf. (1934) 15.sz. 459-464.p. I. rész.

Csendörségi Lapok, XXIV.évf. (1934) 16.sz. 489-493.p. II. rész.

Csendörségi Lapok, XXIV.évf. (1934) 17.sz. 523-527.p. III. rész.

Csendörségi Lapok, XXIV.évf. (1934) 18.sz. 556-562.p. IV. rész.

Szerkesztőségi közlemény: — Szerkesztőségi közlemény: Átszervezték az osztrák csendőrséget. Átszervezték az osztrák csendőrséget. Csendörségi Lapok, XIX.évf. (1929) 25.sz. 801-802.p.

Szerkesztőségi közlemény: Az osztrák csendőrség 1930. évi működése. Csendörségi Lapok, XXI.évf. (1929) 18.sz. 503.p.

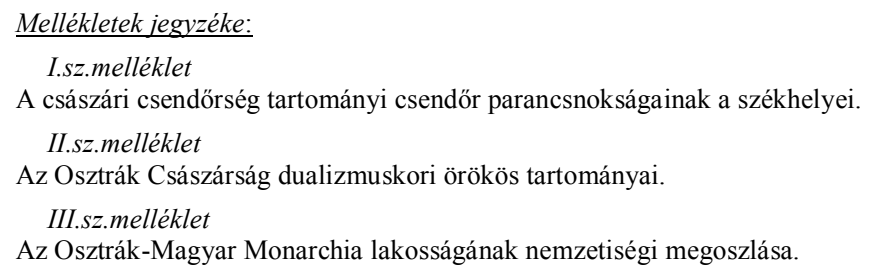




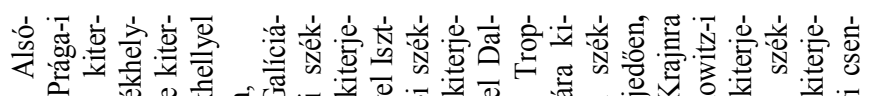

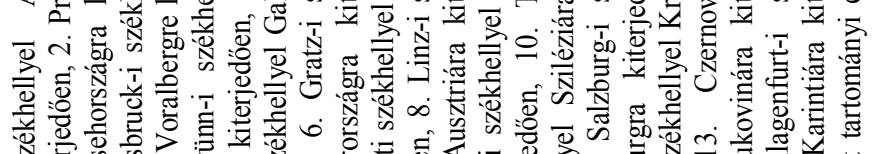

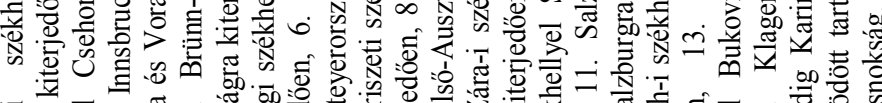

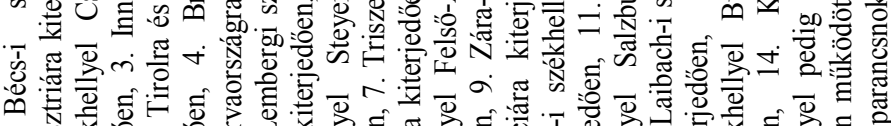

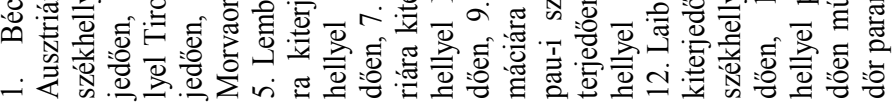

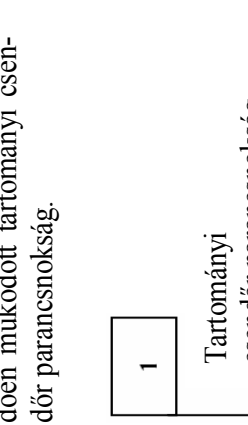

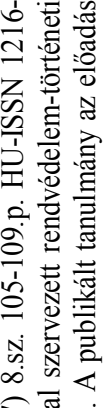

尽㶾涼

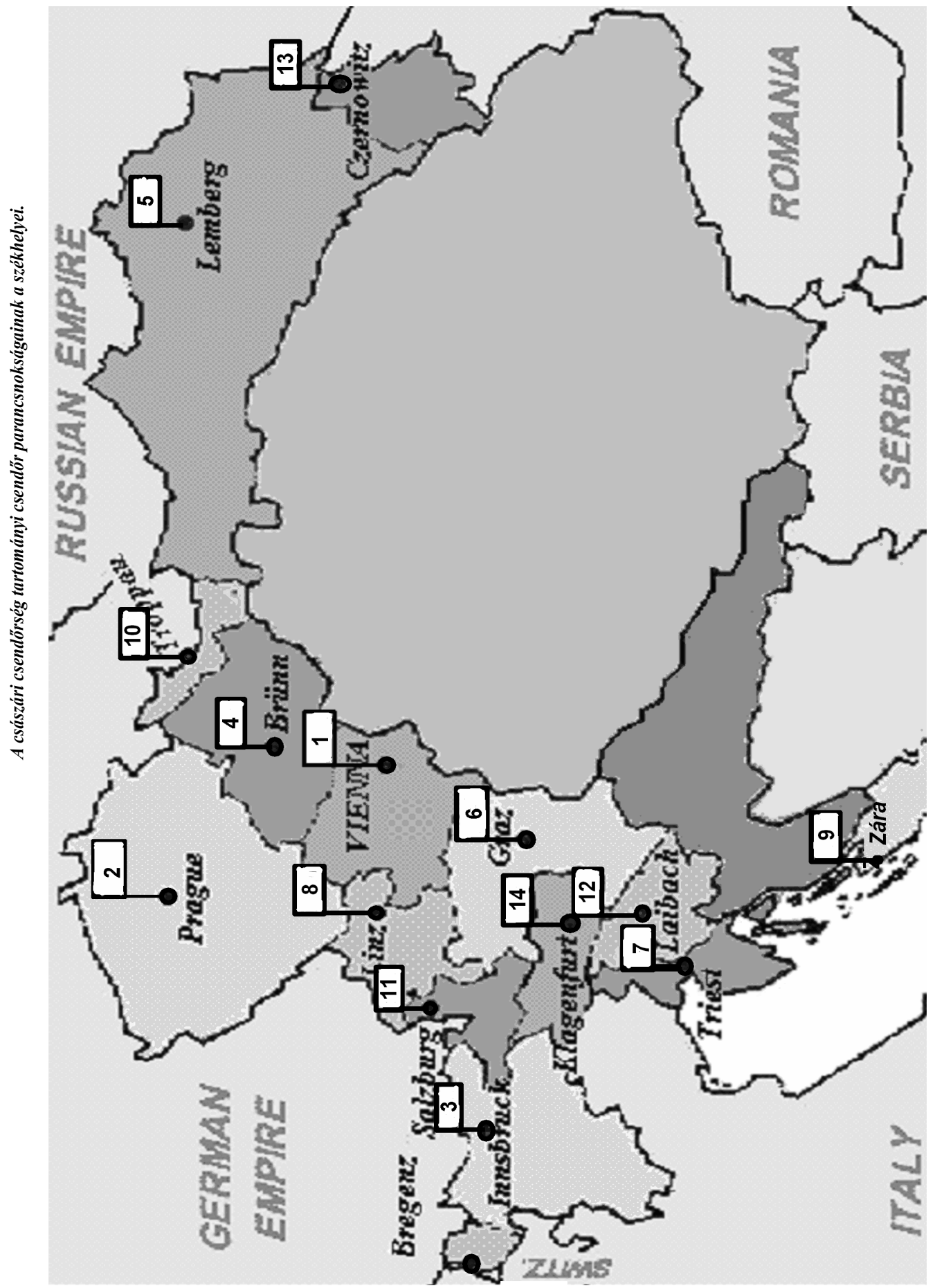


Az Osztrák Császárság dualizmuskori örökös tartományai.

\begin{tabular}{|c|c|c|c|}
\hline S.sz. & Tartomány & Terület & Lakosság \\
\hline 1. & Alsó-Ausztria & $19825 \mathrm{~km}^{2}$ & 634964 fö \\
\hline 2. & Bukovina & $10441 \mathrm{~km}^{2}$ & 845000 fö \\
\hline 3. & Csehország & $51947 \mathrm{~km}^{2}$ & 6679548 fó \\
\hline 4. & Dalmácia & $12831 \mathrm{~km}^{2}$ & 645666 fö \\
\hline 5. & Felső-Ausztria & $11982 \mathrm{~km}^{2}$ & 853000 fö \\
\hline 6. & Felső- és Alsó-Szilézia & $51147 \mathrm{~km}^{2}$ & 756949 fö \\
\hline 7. & Galícia és Lodoméria & $78497 \mathrm{~km}^{2}$ & 8025675 fó \\
\hline 8. & $\begin{array}{l}\text { Görz és Gradiska, Istria, Trieszt } \\
\text { (Osztrák-Illir tengermellék) }\end{array}$ & $7969 \mathrm{~km}$ & 783247 fó \\
\hline 9. & Karintia & $10326 \mathrm{~km}^{2}$ & 369000 fö \\
\hline 10. & Krajna & $9954 \mathrm{~km}^{2}$ & 525995 fó \\
\hline 11. & Morvaország & $22222 \mathrm{~km}^{2}$ & 2622271 fó \\
\hline 12. & Salzburg & $7153 \mathrm{~km}^{2}$ & 214437 fó \\
\hline 13. & Steyer & $22425 \mathrm{~km}^{2}$ & 1144157 fó \\
\hline 14. & Tirol & $26683 \mathrm{~km}^{2}$ & 946613 fó \\
\hline \multicolumn{2}{|c|}{ Osztrák Császárság összesen } & $323577 \mathrm{~km}^{2}$ & 24411000 fö \\
\hline
\end{tabular}

Forrás ! Alexander SixtuEs von Reden: Az Osztrák-Magyar Monarchia. [Österreichisch-Ungarisches Monarchie.] Ford. Blaschtik Éva, Huszár Ágnes, NÉmeth Mária, VÁRnai Péter. Budapest - Salzburg, 1989, Széchenyi Kiadó - Druckhaus Nomital Bückerdienst. 305 p. HU-ISBN 9630272055.

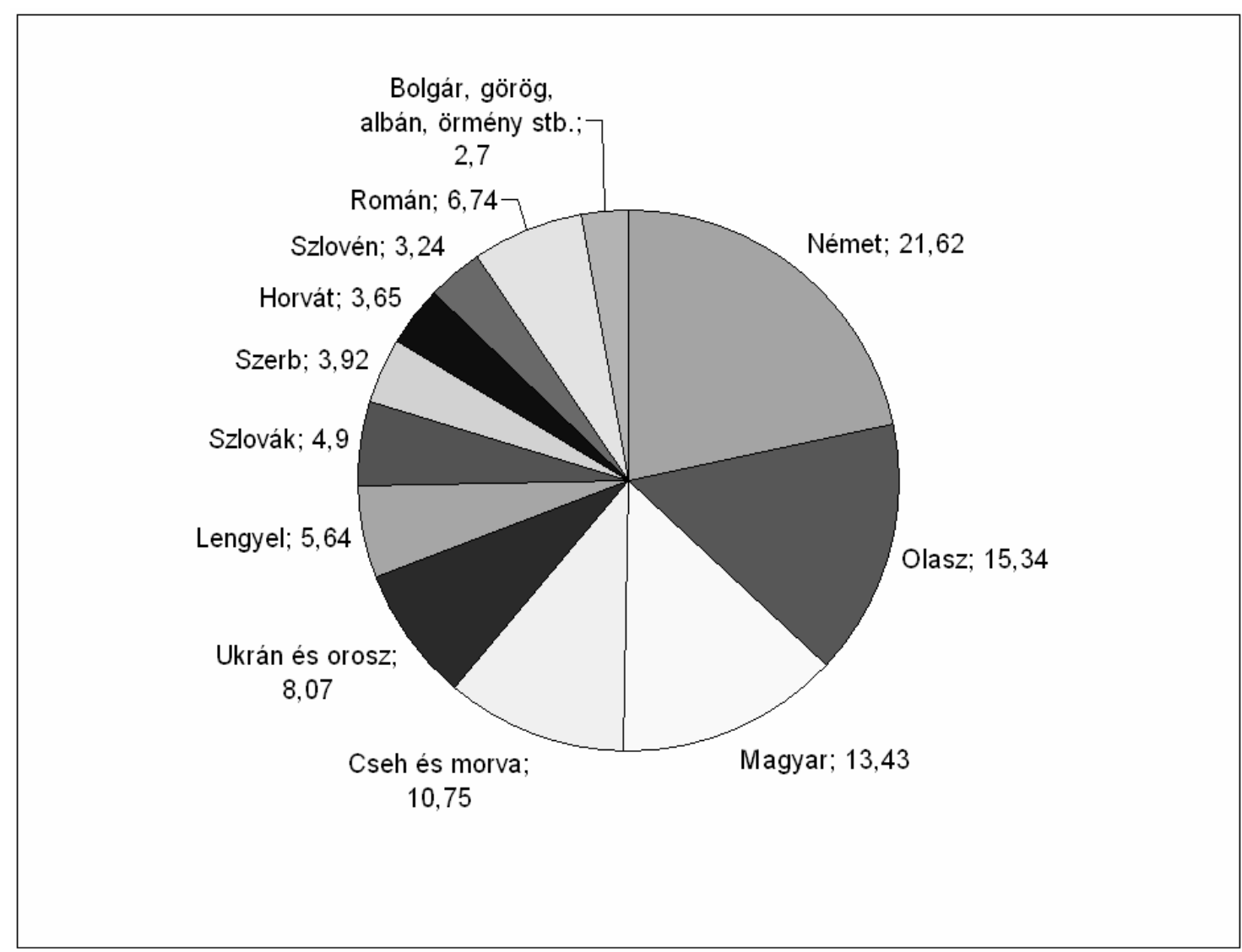

Forrás ! G.K. Cozering: Ehtnographie des Österreichischen Monarchie. [Az osztrák monarchia néprajza.] Wien, 1857, s.n. I.köt. 